\title{
Hubungan Pengetahuan Ibu dan Dukungan Keluarga Terhadap Upaya Pencegahan Infeksi Saluran Pernapasan Akut
}

\section{Correlation Between Mother's Knowledge and Family Support to Acute Respiratory Infection Prevention}

\author{
Ike Niki ${ }^{1)}$, Trias Mahmudiono ${ }^{2)}$ \\ ${ }^{1}$ Rumah Sakit Keluarga Sehat, Jl. P. Sudirman No. 9, Pati, Jawa Tengah, Indonesia \\ ${ }^{2}$ Departemen Gizi, Fakultas Kesehatan Masyarakat, Universitas Airlangga, Surabaya, Indonesia \\ Email : niki_ike@yahoo.co.id
}

\begin{abstract}
Background: Acute Respiratory Infection (ARI) is an infection that occurs in acute respiratory tract such as nose, throat and lungs that can last up to approximately 14 days. The case of ARI in children under five years old in the working area of the Sidotopo Health Center is in the top 10 in the list of diseases. Objective: This study was aimed to look at the relation between knowledge about ARI and family support for prevention of ARI. Method: This research was conducted at RW XIII and RW XIV in Ampel Village with Cross Sectional research and using Chi-Square Test. The population in this study were mothers who have children under five, and in the sample collection using the Simple Random Sampling technique the results obtained were 48 respondents. In efforts to prevent ARI, researchers distinguish between prevention and immunization and nonimmunization. Results: The relation between knowledge and prevention efforts with immunization results are $p=0.011<a=0.05$. The relation of knowledge with prevention of ARI non-immunization, namely exclusive Asi $(p=0.031)$, smoking at home $(p=0.006)$, use of mosquito repellent $(p=0.037)$, and opening the window $(p=0.008)$. The relationship between family support and prevention of $A R I$ with immunization $(p=0.047)$ and non-immunization in the form of exclusive Asi status $(p=0.0001)$. Conclusion: There is a relationship between knowledge and prevention efforts with immunization and nonimmunization (exclusive breastfeeding, smoking in the home, using mosquito coils and opening house windows). There is a relationship between family support and ISPA prevention efforts.
\end{abstract}

Keyword: knowledge, practice, Acute Respiratory Infection, Family Support

\begin{abstract}
ABSTRAK
Latar Belakang: Infeksi Saluran Pernafasan Akut (ISPA) adalah infeksi yang terjadi pada saluran pernafasan akut seperti hidung, tenggorokan, dan paru-paru yang bisa berlangsung hingga kurang lebih 14 hari. Kasus ISPA pada balita di wilayah kerja Puskesmas Sidotopo menempati urutan 10 besar daftar penyakit. Tujuan: Penelitian ini dilakukan untuk melihat hubungan antara pengetahuan tentang ISPA dan dukungan keluarga terhadap upaya pencegahan penyakit ISPA. Metode: Penelitian ini dilakukan di RW XIII dan RW XIV di Kelurahan Ampel dengan penelitian Cross Sectional dan menggunakan Uji Chi-Square. Populasi dalam penelitian ini adalah ibu yang memiliki balita, dan dalam pengambilan sampel menggunakan Teknik Simple Random Sampling didapatkan hasil 48 responden. Dalam upaya pencegahan penyakit ISPA peneliti membedakan antara upaya pencegahan dengan imunisasi dan non imunisasi. Hasil: Hubungan antara pengetahuan dengan upaya pencegahan dengan imunisasi diperoleh hasil $p=0.011<a=0.05$. Hubungan pengetahuan dengan upaya pencegahan penyakit ISPA non imunisasi, yaitu ASI Ekslusif $(p=0,031)$, merokok dalam rumah $(p=0.006)$, penggunaan obat nyamuk $(p=0.037)$, dan membuka jendela $(p=0,008)$. Hubungan antara dukungan keluarga dan upaya pencegahan penyakit ISPA dengan imunisasi $(p=0,047)$ dan non-imunisasi berupa status ASI Ekslusif $(p=0,0001)$. Kesimpulan: Terdapat hubungan antara pengetahuan dengan upaya pencegahan dengan imunisasi dan non imunisasi (ASl eksklusif, merokok dalam rumah, penggunaan obat nyamuk dan membuka jendela rumah). Ada hubungan antara dukungan keluarga dengan upaya pencegahan ISPA.
\end{abstract}


Kata Kunci: pengetahuan, tindakan, dan ISPA, Dukungan Keluarga

\section{PENDAHULUAN}

Infeksi Saluran Pernafasan Akut (ISPA) adalah infeksi yang menyerang saluran pernafasan akut seperti hidung, tenggorokan, dan paru-paru yang bisa berlangsung hingga kurang lebih 14 hari. Penyakit ini juga bisa terjadi pada struktur saluran diatas laring tetapi lebih banyak terjadi pada saluran atas dan bawah yang secara stimulant atau berurutan (Muttaqin, 2008). Dalam buletin pneumonia menurut data WHO menyatakan bahwa penyakit ISPA masih menjadi masalah kesehatan di dunia. Penyakit ISPA dapat dikatakan permasalahan yang penting dalam hal kesehatan karena kasus yang cukup tinggi dan dapat menyebabkan kematian bagi penderitanya terutama bayi dan balita dengan proporsi kematian untuk balita sebesar 19-26\%. ISPA juga termasuk pembunuh utama dan penyebab kematian pada anak usia dibawah lima tahun di dunia.

Kasus ISPA membutuhkan perhatian yang serius tetapi pada kenyataannya saat ini belum terlalu banyak perhatian terhadap penyakit ini. Dari lima balita yang meninggal, satu diantaranya disebabkan oleh Pneumonia. Di dunia kasus kematian balita setiap tahunnya berjumlah 9 juta dan 2 juta diantaranya disebabkan oleh pneumonia. Bisa dikatakan 4 balita meninggal di setiap menitnya.

Di Indonesia Infeksi Saluran pernapasan merupakan penyebab dari $16 \%$ kematian balita, yaitu diperkirakan sebanyak 920.136 balita di tahun 2015. Populasi Angka kematian akibat pneumonia pada balita tahun 2016 sebesar 0,11\% sedangkan tahun 2015 sebesar 0,16\%. Angka kematian akibat pneumonia tahun 2016 pada kelompok umur 1-4 sedikit lebih tinggi yaitu sebesar 0,13\% dibandingkan pada kelompok bayi yang sebesar 0,06\% (Kemenkes RI, 2017).

$$
\text { Prevalensi Infeksi Saluran }
$$

Pernapasan Akut (ISPA) berdasarkan hasil diagnosis dari petugas kesehatan dan keluhan yang disampaikan penduduk adalah 25\% dengan karakteristik penderita penyakit ISPA kelompok umur 1-4 tahun tertinggi yaitu sebesar 25,8 (Balitbangkes Kemenkes RI, 2013).

Penyakit ISPA pada balita dipengaruhi oleh berbagai faktor penyebab diantaranya adalah faktor indvidu itu sendiri (umur, berat badan lahir (BBL), status imunisasi, gizi, dan pemberian ASI Eksklusif), faktor lingkungan (ventilasi, kepadatan hunian di dalam rumah, dan pencemaran udara yang terjadi di alam rumah), dan faktor perilaku seseorang (Maryunani, 2010).

Upaya yang telah dilakukan untuk mengendalikan penyakit ini yaitu dengan meningkatkan penemuan ISPA pada balita. Dalam rangka untuk menurunkan angka kejadian ISPA sangat diperlukan peran petugas kesehatan yaitu terutama yang berhubungan dengan ISPA dan cara pencegahannya. Upaya dalam mencapai tingkat kesejahteraan hidup masyarakat yang optimal memerlukan kesadaran akan pentingnya hidup sehat. Diperlukan pula dukungan faktor lingkungan, perilaku individu, serta penyediaan sarana dan prasana pelayanan kesehatan yang mudah dan terjangkau (accessible). Dalam kegiatan ini upaya pemerintah sangat diperlukan dalam mencapai derajat kesehatan masyarakat yaitu sebagai penyedia fasilitas pelayanan kesehatan, pembuat kebijakan atau peraturan tentang pemnjaminan kesejahteraan dalam hal kesehatan.

Upaya untuk mewujudkan kesejahteraan dalam segi kesehatan juga membutuhkan kerjasama yang kuat antara lembaga pemerintah dengan partisipasi aktif antara para pemangku kepentingan (stekeholder). Selain kerjasama tersebut, peran petugas kesehatan tidak kalah penting dalam menyampaikan berbagai informasi tentang kesehatan. Informasi tersebut diantaranya adalah tentang pencegahan maupun perawatan suatu penyakit kepada orang tua. Orang tua memiliki peranan yang sangat penting, dimana orangtualah yang selalu memantau pertumbuhan dan perkembangan balitanya.

Proses penanganan masalah
kesehatan dapat dilakukan dengan


berbagai cara. Salah satunya dengan cara pencegahan, sehingga ilmu tentang pencegahan terhadap suatu penyakit sangat penting. Masalah kesehatan sangatlah kompleks karena tidak hanya berkaitan dengan faktor kesehatan saja tetapi faktor diluar kesehatan. Begitu pula dalam pemecahan masalah kesehatan tidak hanya dilihat dari segi kesehatan, tetapi harus dilihat dari berbagai faktor yang dapat mempengaruhi paradigma yang ada kaitannya dengan masalah "sehat" dan "sakit" (Mubarak and Chayatin, 2009).

Faktor yang dapat mempengaruhi kesehatan seseorang terdapat empat faktor dari individu maupun masyarkat yaitu keturunan, perilaku, lingkungan, dan pelayanan kesehatan (Mubarak and Chayatin, 2009). Dalam mencapai kesejahteraan atau tingkat kesehatan yang optimal diperlukan tingkat kesadaran dari diri sendiri tentang pentingnya hidup sehat. Kesadaran diri tersebut meliputi upaya dalam melakukan pencegahan terjadinya penyakit yang dimulai dari keluarga. Kasus ISPA yang terjadi pada Balita tak lepas dari peran keluarga, oleh karena itu akan dibahas mengenai tingkat pengetahuan terhadap upaya pencegahan ISPA.

Data Profil Kesehatan Provinsi Jawa Timur Tahun 2012 menyebutkan, angka periode prevalensi ISPA adalah $15,6 \%$ dan terdapat balita dengan Pneumonia sebesar $27,08 \%$ dengan jumlah yang dilaporkan oleh kabupaten/kota adalah 84.392 orang. Data dari Puskesmas Sidotopo yang diperoleh menyatakan bahwa ISPA termasuk ke dalam daftar Top Ten Disesase di wilayah kerja puskesmas tersebut. Kasus ISPA yang tercatat pada tahun 2017 yaitu 2697 kasus. Penduduk disekitar wilayah kerja puskesmas tersebut memiliki pendidikan rendah dan kurangnya kesadaran terhadap kondisi lingkungan sekitar terutama di kelurahan Ampel.

Pengetahuan dipengaruhi oleh tingkat pendidikan yang dimiliki oleh seseorang. Kondisi ini dibuktikan dengan faktor yang mempengaruhi pengetahuan salah satunya adalah pendidikan. Dimana pengetahuan merupakan tingkat ilmu atau pengertian yang dihasilkan dari setelah seseorang tersebut mencari tahu dan melakukan penginderaan pada suatu objek tertentu. Pengetahuan merupakan dasar seseorang untuk menentukan pilihan dan mengambil keputusan dalam bertindak seperti seseorang melakukan upaya pencegahan terhadap suatu penyakit setelah mendapatkan informasi atau setelah melihat dan mencari tahu perihal tersebut (Achmadi, 2014).

Hasil dari observasi yang sudah dilakukan disekitar wilayah kerja Puskesmas Sidotopo yaitu di Kelurahan Ampel. Kelurahan Ampel merupakan daerah padat penduduk. Faktor risiko balita terinfeksi ISPA adalah kebiasaan masyarakat yang sulit mengubah perilakunya untuk hidup bersih dan sehat. Kebiasaan masyarakat tersebut salah satunya adalah tidak menyediakan tempat sampah di sekitar rumah. Tidak sedikit masyarakat yang memiliki kandang hewan ternak yang berada di samping atau disekitar rumah. Beberapa anggota keluarga juga masih ada yang merokok saat sedang berinteraksi dengan balita mereka.

Berdasarkan hasil uraian yang telah dipaparkan, tujuan penelitian ini adalah untuk mengetahui hubungan pengetahuan tentang ISPA dengan upaya pencegahan penyakit ISPA di Kelurahan Ampel Surabaya.

\section{METODE}

Penelitian dilaksanakan di 2 RW di kelurahan Ampel yaitu RW 13 (RT 2 dan RT 3) dan RW 14 (RT 1) di Wilayah kerja Puskesmas Sidotopo sekitar bulan Januari 2018. Jenis penelitian ini adalah observasional dengan menggunakan pendekatan Cross sectional. Data yang diperoleh dari hasil penelitian akan dianalisis dengan uji Chi-Square untuk menganalsis adanya hubungan. Penelitian ini ditunjang dari 2 data yaitu data sekunder dan data primer. Data sekunder di dapatkan dari pihak puskesmas yang berupa dokumen hasil laporan instansi Data primer didapatkan melalui data lapangan. Instrumen pengumpulan data berupa kuesioner.

Populasi penelitian terdiri dari Ibu yang memiliki balita yang berada di 2 RW Keluarahan Ampel yaitu RW 13 (RT 2 dan RT 3) dan RW 14 (RT 1) dengan total ibu yang memiliki balita yaitu 55 ibu. Besar sampel yang di peroleh berdasarkan hasil perhitungan yang dilakukan dengan rumus yaitu 48 orang. Teknik pengambilan sampel yang digunakan pada penelitian ini adalah dengan menggunakan Teknik 
Simple Random Sampling. Teknik Simple Random Sampling yaitu pengambilan sampel dengan tanpa memperhatikan karakteristik responden.

Penelitian ini menggunakan pengukuran pengetahuan dengan 3 kategori yaitu pengetahuan baik, cukup dan kurang. Ibu dikatakan memiliki pengetahuan yang baik apabila jumlah jawaban yang benar adalah 76-100\%, ibu dikatakan memiliki pengetahuan cukup apabila jumlah jawaban benar adalah 56$76 \%$, ibu dikatakan memiliki pengetahuan kurang apabila jumlah jawaban benar $<56 \%$. Variabel yang diteliti dikatakan memiliki hubungan yang bermakna apabila memunuhi syarat yaitu $\mathrm{p}<0,05$.

\section{HASIL DAN PEMBAHASAN}

Hasil pengumpulan data mengenai karakteristik responden penelitian disajikan pada Tabel 1. Tabel 1 menampilkan karakteristik responden. Didapatkan usia ibu terbanyak pada rentang 15-45 tahun. Latar belakang pendidikan terbanyak $(52,1 \%)$ yakni Sekolah Dasar (SD). Mayoritas responden tidak bekerja (50\%) dan memiliki penghasilan antara 500.000-1000.000 rupiah perbulan.

Tabel 1. Karakteristik Responden Berdasarkan Umur, Tingkat Pendidikan, Pekerjaan, dan pendapatan

\begin{tabular}{|c|c|c|}
\hline Karakteristik & Frekuensi & $\%$ \\
\hline \multicolumn{3}{|l|}{ Umur } \\
\hline $15-25$ & 13 & 27,1 \\
\hline $26-35$ & 27 & 56,3 \\
\hline $36-45$ & 8 & 16,6 \\
\hline Total & 48 & 100 \\
\hline \multicolumn{3}{|l|}{ Tingkat pendidikan } \\
\hline SD & 25 & 52,1 \\
\hline SMP & 8 & 16,7 \\
\hline SMA & 14 & 29,2 \\
\hline Perguruan Tinggi & 1 & 2,1 \\
\hline Total & 48 & 100 \\
\hline \multicolumn{3}{|l|}{ Pekerjaan } \\
\hline Pegawai swasta & 7 & 14,6 \\
\hline Wiraswasta & 17 & 35,4 \\
\hline Tidak Bekerja & 24 & 50 \\
\hline Total & 48 & 100 \\
\hline \multicolumn{3}{|l|}{ Pendapatan (Rupiah) } \\
\hline $500.000-1.000 .0000$ & 19 & 39,6 \\
\hline $1.000 .000-1.500 .000$ & 12 & 25 \\
\hline $1.5000 .000-2.000 .000$ & 5 & 10,4 \\
\hline $2.0000 .0000-3.000 .000$ & 9 & 18,8 \\
\hline$>3.000 .000$ & 3 & 6,3 \\
\hline Total & 48 & 100 \\
\hline
\end{tabular}

Hasil Pengetahuan Ibu terhadap Penyakit ISPA

Hasil pengumpulan data menunjukkan bahwa sebanyak 28 orang $(58,33 \%)$ memiliki pengetahuan yang kurang tentang ISPA. Hasil analisis data dapat disimpulkan bahwa Ibu di kelurahan Ampel Khususnya di RW XIII dan RW IX belum mengetahui tentang penyakit ISPA yang meliputi definisi, tanda dan gejala, penyebab bahkan upaya untuk mencegah penyakit ISPA tersebut.
Pengetahuan responden masih kurang terkait pemahaman erhadap penyakit ISPA. Kondisi ini bisa dilihat dari karakteristik tingkat pendidikan terakhir diselesaikan oleh responden, dimana mayoritas responden hanya berpendidikan terakhir lulus SD, sehingga dapat mempengaruhi tingkat pengetahuan yang dimiliki.

Hasil penelitian ini sejalan dengan penelitian sebelumnya yang menyebutkan adanya korelasi antara tingkat pendidikan 
terhadap status kesehatan seseorang (Pradono and Sulistyowati, 2014). Tingkat pendidikan adalah berapa lama seseorang menyelesaikan pendidikan yang ditempuh baik pendidikan formal seperti sekolah negeri, swasta, maupun pendidikan seperti keagamaan. Seseorang yang memiliki pendidikan cukup baik dapat meningkatkan intelektual, sehingga semakin tinggi tingkat pendidikan yang dimiliki atau yang telah diselesaikan oleh seseorang akan mempermudah dalam menerima dan memahami suatu informasi yang diperoleh dari luar. Tingkat pemahaman ini kemudian mempengaruhi keputusan pada suatu keadaan yang dihadapi dengan tepat.

Pendidikan adalah suatu proses dari perubahan perilaku dan sikap seseorang dengan melalui suatu kegiatan pemebelajaran dan pengajaran (Budiman and Riyanto, 2013). Semakin tinggi pendidikan yang dimiliki oleh seseorang, maka akan semakin cepat dan mudah pula orang tersebut dalam menerima dan memahami informasi yang diperoleh. Umumnya pendidikan memberikan dan mengajarkan seseorang tentang berbagai ilmu sehingga seseorang itu mampu untuk berfikir secara rasional, logis dalam melihat maupun menghadapi berbagai isuisu yang terjadi dari berbagai sudut pandang. Dengan pendidikan yang dimiliki seseorang mampu dalam menganalisis dan memecahkan bahkan memberi solusi.

\section{Hubungan Pengetahuan tentang penyakit ISPA dengan Upaya pencegahan penyakit ISPA}

Hasil analisis nilai hasil uji statistik yang telah dilakukan, didapatkkan $p=0,011$, sehingga nilai $p<a=0,05$. Hasil ini menunjukkan bahwa terdapat hubungan antara pengetahuan yang dimiliki seseorang terhadap pemberian imunisasi dasar sebagai salah satu upaya yang dilakukan untuk mencegah terhadap penyakit ISPA.
Adanya hubungan ini memiliki makna bahwa tingkat pengetahuan seseorang sangat berpengaruh terhadap hal yang dilakukan. Dimana tingkat pengetahuan ibu tentang ISPA akan berdampak terhadap upaya pencegahan yang dilakukan dengan cara memberikan Imunisasi sebagai dasar pencegahan terhadap suatu penyakit.

Hasil ini sejalan dengan penelitian sebelumnya, yang menyatakan bahwa adanya hubungan yang kuat antara pengetahuan ibu dengan status pemberian imunisasi dasar (Kadir, Fatimah and Hadia, 2014). Didukung dengan penelitian sebelumnya dengan hasil bahwa seseorang tidak akan mempunyai dasar mengambil suatu keputusan dan menentukan tindakan tentang upaya yang harus dilakuakn terhadap pencegahan suatu penyakit tanpa adanya pengetahuan (Achmadi, 2014).

Terdapat hubungan pengetahuan yang dimiliki ibu dengan status pemberian imunisasi dasar untuk bayinya. Dalam penelitian tersebut juga menyebutkan bahwa ibu yang memiliki pengetahuan yang baik mayoritas status imunisasi dasar ankanya lengkap dan dijelaskan pula bahwa ibu dengan pengetahuan baik memolki 6,2 kali bayinya memiliki imunisasi dasar yang lengkap (Isnayni, 2016).

Imunisasi adalah suatu tindakan yang sengaja dilakukan dengan memasukan cairan yang didalamnya mengandung mikroba hidup yang dilemahkan kepada bayi dan anak dengan tujuan untuk memberikan kekebalan tubuh bayi dan anak terhadap suatu penyakit tertentu. Imunisasi merupakan salah satu upaya pencegahan terhadap suatu penyakit. Meskipun suatu saat nanti anak terpapar oleh penyakit bisa terhindar dari penyakit tersebut ataupun terkena sakit tetapi tidak terlalu parah kondisinya.

Tabel 2. Hasil Korelasi antara Pengetahuan dengan Upaya Pencegahan ISPA melalui Imunisasi

\begin{tabular}{|c|c|c|c|c|c|}
\hline \multirow{3}{*}{ Pengetahuan } & \multicolumn{4}{|c|}{ Status Imunisasi } & \multirow{3}{*}{$\begin{array}{c}\text { P } \\
\text { Value }\end{array}$} \\
\hline & \multicolumn{2}{|c|}{ Lengkap } & \multicolumn{2}{|c|}{ Tidak Lengkap } & \\
\hline & Frekuensi & $\%$ & Frekuensi & $\%$ & \\
\hline Baik & 10 & 20,8 & 1 & 2,1 & \\
\hline Cukup & 4 & 8,3 & 5 & 10,4 & 0,011 \\
\hline Kurang & 8 & 16,7 & 20 & 41.7 & \\
\hline Total & 22 & 45,8 & 26 & 54,2 & \\
\hline
\end{tabular}


Pengetahuan yang dimiliki seseorang dalam memberikan status imunisasi dasar lengkap dipengaruhi 3 faktor, yaitu:

1. Umur

Umur adalah kondisi usia seseorang yang terhitung mulai dari semenjak dirinya dilahirkan. Semakin umur seseorang bertambah akan berbanding lurus dengan tingkat kematangan pola pikir sehingga pengetahuannya juga akan bertambah.

2. Pendidikan

Pendidikan adalah suatu proses bimbingan pembelajaran atau pengajaran yang ditujukan kepada seseorang dalam mempermudah mencapai cita-cita tertentu. Dengan memiliki tingkat pendidikan yang tinggi akan mempermudah dalam memahami dan menganalisa suatu hal.

3. Paritas

Paritas adalah jumlah anak yang dimiliki dan yang dilahirkan dalam kondisi hiudp maupun sudah meninggal.

Hasil yang di dapatkan oleh peneliti ada kesesuaian dengan teori pengetahuan merupakan suatu bagian yang penting dalam penentuan tindakan yang akan dilakukan seseorang (Notoatmodjo, 2010). Seseorang memiliki pengetahuan bisa berdasarkan pengalaman sendiri atau hasil dari melihat atau mendengar pengalaman yang dirasakan oleh orang lain. Contohnya, seorang ibu melihat anak tetangganya yang tidak mendapatkan imunisasi lengkap mudah sakit, atau anak tetangga yang tidak mendapatkan imunisasi campak terkena campak sehingga seseorang tersebut tidak mau hal yang sama terjadi pada anaknya. Sehingga anaknya mendapatkan imunisasi sebagai upaya pencegahan dari penyakit sesuai dengan pengetahuan ibu yang di dapatkan dari pengalaman yang dirasakan oleh orang lain. Pengetahuan yang dimiliki oleh ibu tentang penyakit ISPA akan menimbulkan tindakan pencegahan agar anaknya tidak terkena ISPA dengan memberikan imunisasi sebagai pencegahan terhadap suatu penyakit.

Pengetahuan yang dimiliki seseorang dengan orang lain berbedabeda. Pengetahuan merupakan kekayaan mental secara langsung atau tidak langsung dapat memperkaya kehidupan seseorang. Pengetahuan yang baik akan berdampak terhadap dengan tindakan pencegahan terhadap penyakit ISPA. Pengalaman yang dimiliki oleh seseorang bisa berasal dari pengalaman sendiri ataupun dari kegiatan yang menunjang, melihat atau mengamati suatu kondisi yang berada di lingkungannya. Pengetahuan merupakan suatu hal dasar untuk terbentuknya tindakan yang akan dilakukan seseorang. Pengetahuan yang dimiliki seseorang akan menciptakan tindakan dasar dalam kehidupan seseorang.

Tabel 3. Hasil Korelasi antara Pengetahuan dengan Upaya Pencegahan melalui Non Imunisasi

\begin{tabular}{|c|c|c|c|c|c|c|c|c|c|}
\hline \multirow{3}{*}{$\begin{array}{l}\text { Upaya Pencegahan } \\
\text { Non Imunisasi }\end{array}$} & \multicolumn{6}{|c|}{ Tingkat Pengetahuan } & \multirow{2}{*}{\multicolumn{2}{|c|}{ Total }} & \multirow{3}{*}{$\begin{array}{c}P \\
\text { Val } \\
\text { ue }\end{array}$} \\
\hline & \multicolumn{2}{|c|}{ Baik } & \multicolumn{2}{|c|}{ Cukup } & \multicolumn{2}{|c|}{ Kurang } & & & \\
\hline & $\mathrm{n}$ & $\%$ & $\mathrm{n}$ & $\%$ & $\mathrm{n}$ & $\%$ & $\mathbf{n}$ & $\%$ & \\
\hline \multicolumn{10}{|l|}{ ASI Eksklusif } \\
\hline $\mathrm{Ya}$ & 8 & 16,7 & 7 & 14,6 & 11 & 22,9 & 26 & 54,2 & 0,0 \\
\hline Tidak & 3 & 6,3 & 2 & 4,2 & 17 & 35,3 & 22 & 45,8 & 31 \\
\hline \multicolumn{10}{|l|}{ Merokok } \\
\hline $\mathrm{Ya}$ & 4 & 8,3 & 3 & 6,3 & 22 & 45,8 & 29 & 60,4 & 0,0 \\
\hline Tidak & 7 & 14,6 & 6 & 12,5 & 6 & 12,5 & 19 & 39,6 & 06 \\
\hline \multicolumn{10}{|c|}{ Penggunaan Obat Nyamuk } \\
\hline $\mathrm{Ya}$ & 5 & 10,4 & 2 & 4,2 & 20 & 41,7 & 27 & 56,3 & 0,0 \\
\hline Tidak & 6 & 12,5 & 7 & 14,6 & 8 & 16,7 & 21 & 43,8 & 37 \\
\hline \multicolumn{10}{|l|}{ Membuka Jendela } \\
\hline $\mathrm{Ya}$ & 10 & 20,8 & 7 & 14,6 & 12 & 25 & 29 & 60,4 & 0,0 \\
\hline Tidak & 1 & 2,1 & 2 & 4,2 & 16 & 33,3 & 19 & 39,6 & 08 \\
\hline
\end{tabular}

Penelitian sebelumnya juga menunjukkan hasil serupa, dimana salah satu upaya pencegahan penyakit ISPA adalah melalui pemberian imunisasi (Misnadiarly, 2008). Keadaan lingkungan dikatakan tidak sehat disebabkan karena pencemaran udara seperti asap kendaraan, asap yang berasal dari obat nyamuk, rokok, maupun asap yang dihasilkan dari dapur. Keberadaan asap 
tersebut bisa memicu timbulnya ISPA (Depkes RI, 2010)

Anak memiliki dua macam kekebalan tubuh, yaitu imun aktif dan pasif. Banyak cara untuk meningkatkan sitem kekebalan tubuh pada anak-anak. Cara yang paling mudah yakni dengan memberikan ASI pada anak secara ekslusif selama 6 bulan tanpa tambahan makanan apapun. Pemberian ASI ekslusif bisa meningkatkan sistem kekebalan tubuh. ASI mengandung banyak nutrisi yang cukup untuk memenuhi kebutuhan dan mampu meningkatkan kekebalan. Kandungan yang terdapat dalam ASI seperti vitamin, protein, dan kalori yang banyak diperlukan oleh tubuh. Upaya pencegahan ini dimaksudkan untuk meningkatkan sistem imun sehingga anak dapat terlindungi dari berbagai penyakit infeksi sepeti ISPA.

Hasil yang didapatkan dari penelitian yang dilakukan ini sejalan dengan hasil penelitian sebelumnya yang menyatakan bahwa terdapat perbedaan yang signifikan antara kejadian penyakit infeksi pada anak yang diberi ASI eksklusif dengan yang tidak diberi ASI eksklusif. Anak yang tidak mendapat ASI eksklusif memiliki risiko 4,96 lebih besar terkena ISPA dibandingkan anak yang diberikan ASI ekslusif oleh ibunya (Yustianingrum and Adriani, 2017).

Hasil uji statistik diperoleh nilai $\mathrm{p}=0,006 \quad(\mathrm{p}<\mathrm{a}=0,05)$, yang artinya ada hubungan pengetahuan ibu tentang penyakit ISPA terhadap tindakan untuk tidak membiarkan anggota keluarga merokok di dalam rumah. Asap rokok mengandung zat kimia yang berbahaya untuk kesehatan, seperti tar, nikotin, dan karbon monoksida. Asap tersebut dikeluarkan akibat pembakaran produk tembakau yang berbahaya bagi kesehatan manusia. Bayi dan anak-anak yang orangtuanya merupakan perokok aktif mempunyai risiko lebih besar untuk terkena gangguan pernafasan dengan gejala sesak nafas, batuk, dan lendir yang berlebihan.

Penelitian ini sejalan dengan penelitian sebelumnya yang menyatakan bahwa dari $25,9 \%$ balita di Indonesia yang terpajan asap rokok di dalam rumahnya, sebesar 24,4\% diantaranya menderita ISPA. Dapat disimpulkan bahwa dalam pengendalian penyakit ISPA pada balita di sarankan untuk berfokus terhadap pajanan asap rokok dalam rumah (Zahra and Assetya, 2017). Penelitian sebelumnya menyatakan gangguan fungsi paru-paru yang dialami oleh seseorang dapat disebabkan oleh merokok, durasi paparan terhadap debu. Faktor internal yaitu umur, jenis kelamin, status gizi, kebiasaan berolahraga juga berperan dalam menimbulkan gangguan pada fungsi paru-paru (Sholihah and Tualeka, 2015).

Hasil penelitian menunjukkan nilai $p=0,037 \quad(a=0,05)$, memiliki makna bahwa terdapat hubungan antara pengetahuan ibu yang memilki balita ISPA dengan penggunaan obat nyamuk dalam rumah. Upaya pencegahan selanjutnya yang diteliti yaitu kebiasaan membuka jendela di pagi hari. Hasil yang diperoleh dari penelitian yang dilakukan ini nilai $p=0,008$ $(a=0,05)$, yang memiliki makna bahwa ada hubungan yang signifikan antara pengetahuan ibu terhadap tindakan ibu membuka jendela di pagi hari.

Hasil penelitian yang telah dilakukan sejalan dengan penelitian yang menyatakan salah satu faktor dari penyebab penyakit ISPA adalah kurangnya pencahayaan yang didapat anak. Dimana pencahayaan yang dimaksud bisa diperoleh dengan membuka jendela di pagi hari. Pemenuhan udara bersih merupakan kebutuhan utama dalam mempercepat proses penyembuhan ISPA. Ventilasi adalah tempat keluar masuknya udara secara bebas. Ventilasi berfungsi untuk menjaga aliran udara yang masuk tetap segar dan terjaga seperti keseimbangan oksigen yang dibutuhkan oleh orang yang menjadi penghuni rumah tersebut. Banyak manfaat yang diperoleh dari adanya ventilasi di rumah seperti menjaga agar aliran udara yang berada di dalam rumah tersebut tetap bersih dan segar. Ventilasi di rumah harus cukup dan sesuai, karena kurangnya ventilasi di dalam rumah dapat menimbulkan jumlah oksigen dalam rumah itu berkurang, sedangkan kadar karbondioksida yang berbahaya justru meningkat.

Perilaku membuka jendela dan keberadaan jendela merupakan bagian dari ciri rumah sehat, dimana dengan keberadaan jendela dapat menjaga sirkulasi udara yang baik di dalam rumah dan memiliki pengaruh penting terhadap kejadian gangguan pernapasan pada balita. Pencahayaan dari sinar matahari sagat dibutuhkan untuk kondisi rumah yang dikatakan sehat dan pencahayaan dari sinar matahari itu harus cukup. 
Pencahayaan dari sinar matahari yang kurang dapat menimbulkan berbagai masalah seperti menimbulkan ketidaknyamanan penghuni karena kondisi rumah yang lembab dan dapat menjadi tempat berkembangbiak kuman-kuman penyebab penyakit. Kondisi ini terjadi karena proses penguapan cairan dari permukaan kulit. Tempat yang lembab menjadi media dari bakteri-bakteri pathogen penyebab penyakit seperti tuberculosis, penyakit saluran pernafasan, dan penyakit mata, sehingga perlu diupayakan untuk membuka jendela atau ventilasi rumah secara rutin.

Faktor yang bisa mempengaruhi tingkat pengetahuan salah satunya yaitu pendidikan. Pendidikan adalah proses pelatihan dan pembelajaran yang telah ditempuh seseorang. Tingginya pendidikan yang dimiliki oleh seseorang berbanding lurus dengan kemampuan untuk memahami informasi yang diperoleh. Tingkat pengetahuan yang baik dapat mempengaruhi seseorang dalam melakukan suatu hal atau mengambil keputusan (Budiman and Riyanto, 2013).

Pengetahuan merupakan bagian yang sangat penting dalam proses perubahan perilaku seseorang. Tingkat pengetahuan seseorang dapat diketahui melalui pemahaman mereka terhadap suatu informasi atau fenomena. Pemahaman tersebut kemudian akan berlanjut pada implementasi, analisis, sintesis, dan evaluasi untuk menilai suatu keadaan. Contohnya yakni seseorang yang memiliki pengetahuan terhadap ISPA akan mampu membedakan balita yang terkena ISPA dengan yang tidak (Achmadi, 2014).

\section{Pengetahuan}

Pengetahuan adalah hasil penginderaan manusia, atau hasil tahu terhadap suatu objek melalui indera yang dimilikinya seperti: mata, hidung, telinga, dan sebagaianya (Notoatmodjo, 2010). Ada 6 tingkatakan dalam pengetahuan, yaitu (Notoatmodjo, 2010):

1. Tahu (know)

Dijabarkan sebagai pengingat dari suatu materi yang telah dipelajari sebelumnya, atau sebagai recall (memanggil) sesuatu yang spesifik dari yang dipelajari atau rangsangan yang telah diterima sebelumnya.

2. Memahami (comprehension)

Kemampuan dalam menjelaskan suatu hal atau objek yang diketahuinya.
Tidak hanya dari mampu menyebutkan saja, tetapi juga mampu dalam mengintepretasikan hal tersebut secara benar.

3. Aplikasi (application)

Apabila seseorang yang sudah memahami suatu hal yang sudah didapatkan maupun yang dipelajarinya sehingga dapat menerapkan dan mengaplikasikan suatu objek tersebut pada keadaan yang lainnya.

4. Analisa (analysis)

Kemampuan seseorang untuk menjabarkan, memisahkan, dan mengelompokkan materi atau suatu objek ke dalam komponen-komponen.

5. Sintesis (synthesis)

Kemampuan seseorang dalam merangkum dan menempatkan ke dalam suatu hubungan yang logis dari komponen pengetahuan yang dimilikinya.

6. Evaluasi (evaluation)

Kemampuan seseorang dalam menilai objek tertentu yang sudah di tentukan sebelumnya.

Faktor yang mempengaruhi pengetahuan meliputi (Budiman and Riyanto, 2013):

1. Pendidikan

Suatu kegiatan pembelajaran, pengajaran, atau pelatihan yang dijalani oleh seseorang untuk memperoleh suatu hal dalam proses pendewasaan diri. Seseorang yang memiliki tingkat pendidikan tinggi maka akan cepat pula dalam menerima informasi dan memahami informasi tersebut.

2. Informasi/Media Massa

Informasi adalah suatu pesan atau kumpulan dari pesan yang berisi berbagai hal dengan maksud tertentu dalam penyebarannnya.

3. Sosial, Budaya, dan Ekonomi

Budaya yang dimiliki oleh seseorang dilakukan melalui tradisi yang turun menurun dan biasanya tanpa penalaran tentang baik buruknya budaya tersebut. Status ekonomi seseorang mempengaruhi tingkat pengetahuan. Orang yang memiliki status ekonomi dibawah rata-rata akan mengalami kesulitan dalam memperoleh fasilitas yang diperlukan untuk meningkatkan pengetahuan. Seseorang yang mempunyai status sosial budaya yang baik, maka pengetahuannya akan baik pula.

4. Lingkungan 
Lingkungan merupakan faktor eksternal yang dapat mempengaruhi pengetahuan. Lingkungan tersebut meliputi lingkungan pergaulan, pertemanan, atau perkumpulan. Melalui lingkungan tersebut, seseorang akan memperoleh penemuan yang baru tentang berbagai hal yang belum diketahuinya. Baik buruknya pengetahuan yang didapat tergantung dari lingkungan dan juga pilihan individu tersebut.

5. Pengalaman

Diperoleh dari diri sendiri maupun orang lain. Pengalaman yang diperoleh dapat menambah pengetahuan yang akan bermanfaat dalam menghadapi suatu masalah yang sama dikemudian hari.

6. Usia

Dihitung dari hari kelahiran sampai saat ini. Pertambahan usia berbanding lurus dengan pengalaman yang diperoleh dan dapat mempengaruhi pola pikir individu dalam menyelesaikan permasalahan yang dihadapi.

Faktor risiko terjadinya ISPA terdiri dari faktor individu, lingkungan, ventilasi rumah, dan kepadatan hunian (jumlah penghuni dalam rumah) dan perilaku (Maryunani, 2010). Hasil penelitian ini sejalan dengan penelitian sebelumnya yang menyatakan bahwa terdapat hubungan antara pengetahuan, ventilasi udara, dan kebiasaan merokok dengan kejadian ISPA (Pangaribuan, 2017).

Sejumlah penelitian yang ada telah membuktikan bahwa faktor risiko yang erat hubungannya dengan penyakit ISPA pada balita, yaitu faktor kondisi lingkungan rumah dan faktor balita (seperti pemberian ASI eksklusif, status gizi, status imunisasi, berat badan lahir dan umur bayi). Kondisi lingkungan rumah yang berpengaruh terhadap kejadian penyakit ISPA yaitu pajanan asap rokok di dalam rumah, pajanan asap dapur yang di sebabkan oleh memasak dengan menggunakan bahan bakar kayu, dan buruknya sirkulasi udara di dalam rumah.

Pencegahan ISPA dapat dilakukan melalui berbagai hal, yakni melalui pemberian imunisasi dan pencegahan non imunisasi. Pencegahan non imunisasi terdiri dari pemberian ASI ekslusif, mengurangi paparan asap rokok, penggunaan obat nyamuk dalam rumah, dan membuka jendela atau ventilasi rumah setiap pagi (Misnadiarly, 2008).

Tabel 4. Hasil Korelasi antara dukungan keluarga dengan upaya pencegahan melalui imunisasi dan non-imuniasi

\begin{tabular}{|c|c|c|c|c|c|c|c|}
\hline \multirow{3}{*}{ Upaya Pencegahan } & \multicolumn{4}{|c|}{ Variabel Dukungan Keluarga } & \multirow{2}{*}{\multicolumn{2}{|c|}{ Total }} & \multirow{3}{*}{$\begin{array}{c}\mathrm{P} \\
\text { Value }\end{array}$} \\
\hline & \multicolumn{2}{|c|}{ Ada } & \multicolumn{2}{|c|}{ Tidak Ada } & & & \\
\hline & Frekuensi & $\%$ & Frekuensi & $\%$ & Frekuensi & $\%$ & \\
\hline \multicolumn{8}{|l|}{ Imunisasi } \\
\hline Lengkap & 14 & 29,2 & 8 & 16,6 & 22 & 45,8 & \multirow{2}{*}{0,047} \\
\hline Tidak Lengkap & 8 & 16,7 & 18 & 37,5 & 26 & 54,2 & \\
\hline \multicolumn{8}{|l|}{ Non-imunisasi } \\
\hline ASI Eksklusif & 26 & 54,2 & 0 & 0 & 26 & 54,2 & \multirow{2}{*}{0,0001} \\
\hline Tidak ASI Eksklusif & 0 & 0 & 22 & 45,8 & 22 & 45,8 & \\
\hline
\end{tabular}

\section{Hasil Dukungan Keluarga terhadap Upaya Pencegahan ISPA}

Hasil dari uji statistik yang dilakukan oleh peneliti dari upaya pencegahan dengan imunisasi diperoleh nilai $p=0,047$, sehingga nilai $p<a=0,05$ yang berarti ada hubungan yang signifikan antara dukungan keluarga terhadap kelengkapan status imunisasi dasar sebagai salah satu upaya pencegahan terhadap penyakit ISPA. Hasil penelitian yang telah dilakukan sejalan dengan penelitian sebelumnya, bahwa terdapat hubungan yang signifikan antara dukungan keluarga memiliki terhadap kelengkapan status imunisasi dasar pada anak (Hafid,
Martini and Devy, 2016). Peran dukungan keluarga yang diperoleh akan sangat berdampak yang luar biasa terhadap status kelengkapan imunisasi pada anak (Oktarina, 2018).

Hasil dari uji statistik yang telah dilakukan didapatkan nilai $\mathrm{p}=0,0001$ yang artinya nilai $\mathrm{p}<\mathrm{a}=0,05$ sehingga dapat ditarik kesimpulan bahwa terdapat hubungan yang bermakna antara dukungan keluarga yang diperoleh ibu terhadap kesuksesan dalam memberikan ASI Eksklusif.

Dukungan keluarga yang diberikan bisa berupa mendengarkan keluhan ibu selama menyusui, memotivasi dan 
memberikan semangat kepada ibu untuk tidak takut akan perubahan fisik yang terjadi, misalnya gemuk, serta meyakinkan bahwa ibu dapat memberikan ASI ekslusif selama 6 bulan. Kesuksesan seorang Ibu dalam memberikan ASI Ekslusif pada anaknya tidak lepas dari peran dukungan keluarga yang diperoleh.

\section{SIMPULAN}

Kesimpulan dari penelitian ini
yakni terdapat hubungan antara
pengetahuan ibu tentang penyakit ISPA
terhadap upaya pencegahan ISPA baik
melalui imunisasi maupun non imunisasi.
Pencegahan non imunisasi dilakukan
melalui pemberian ASI eksklusif,
kebiasaan merokok dalam rumah,
kebiasaan membuka ventilasi, dan
penggunaan obat nyamuk.

\section{DAFTAR PUSTAKA}

Achmadi, U. F. (2014) Kesehatan Masyarakat Teori dan Aplikasi. Jakarta: PT Raja Grafindo Persada.

Balitbangkes Kemenkes RI (2013) PokokPokok Hasil Riset Kesehatan Dasar (Riskesdas) 2013 Provinsi Jawa Timur.

Budiman and Riyanto, A. (2013) Kapita Selekta Kuisioner Pengetahuan Dan Sikap Dalam Penelitian Kesehatan. Jakarta: Salemba Medika.

Depkes RI (2010) Profil Kesehatan Indonesia. Jakarta: Kementerian Kesehatan Republik Indonesia. Available at: https://www.depkes.go.id/resour ces/download/pusdatin/profilkesehatan-indonesia/profilkesehatan-indonesia-2009.pdf.

Hafid, W., Martini, S. and Devy, S. R. (2016) 'Faktor Determinan Status Imunisasi Dasar Lengkap Pada Bayi Di Puskesmas Kondang dan Geger', Jurnal Wiyata, 3(1), pp. 38-45.

Isnayni, E. (2016) 'Hubungan Pengetahuan Ibu, Pendapatan Keluarga dan Peran Keluarga dengan Status Imunisasi Dasar', Jurnal Berkala Epidemiologi, 4(3), pp. 360-370. doi: $10.20473 /$ jbe.v4i3.

Kadir, L., Fatimah and Hadia, H. (2014)
'Pengetahuan dan Kepatuhan Ibu pada Pemberian Imunisasi Dasar bagi Bayi', Journal of Pediatric Nursing Stikes Nani Hasanuddin Makassar, 1(1), pp. 9-13.

Kemenkes RI (2017) Profil Kesehatan Indonesia 2016, Kementerian Kesehatan Republik Indonesia. Jakarta: Kementerian Kesehatan Republik Indonesia. Available at: http: / / www.depkes.go.id/ resourc es/download/pusdatin/profilkesehatan-indonesia/ProfilKesehatan-Indonesia-2016.pdf.

Maryunani, A. (2010) Ilmu Kesehatan Anak Dalam Kebidanan. Jakarta: CV. Trans Info Media.

Misnadiarly (2008) Infeksi Saluran Napas Pneumonia pada Anak, Orang Dewasa, Usia Lanjut, Pneumonia Atipik \& Pneumonia Atypik Mycobacterium. Jakarta: Pustaka Obor Populer.

Mubarak, W. . and Chayatin (2009) IImu Kesehatan Masyarakat Teori dan Aplikasi. Jakarta: Salemba Medika.

Muttaqin, A. (2008) Buku Ajar Asuhan Keperawatan Klien dengan Gangguan Sistem Pernapasan. Jakarta: Salemba Medika.

Notoatmodjo, S. (2010) Promosi Kesehatan Teori \& Aplikasi. Jakarta: Rineka Cipta.

Oktarina, S. (2018) 'Hubungan Peran Kader Dan Dukungan Keluarga Dengan Kelengkapan Imunisasi Dasar Pada Bayi Di Wilayah Kerja Puskesmas Tarusan', Menara Ilmu, 12(80), pp. 111-118.

Pangaribuan, S. (2017) 'Hubungan Kondisi Lingkungan Rumah dengan Kejadian ISPA pada Balita di Puskesmas Remu Kota Sorong', Global Health Science, 2(1), pp. 6-10.

Pradono, J. and Sulistyowati, N. (2014) 'Hubungan antara Tingkat Pendidikan, Pengetahuan tentang Kesehatan Lingkungan, Perilaku Hidup Sehat dengan Status Kesehatan (Studi Korelasi pada Penduduk Umur 10-24 Tahun di Jakarta Pusat)', Buletin Penelitian Sistem Kesehatan, 17(1), pp. 89-95. Available at: https: / /media.neliti.com/media/ publications/20885-ID-correlationbetween-education-level- 
192 Jurnal Promkes: The Indonesian Journal of Health promotion and Health Education Vol. 7 No. 2 Desember 2019 : 182 - 192, doi: 10.20473/jpk.V7.12.2019.182-192

knowledge-of-environmentalhealth-healthy-be.pdf.

Sholihah, M. and Tualeka, A. R. (2015) 'Studi Faal Paru Dan Kebiasaan Merokok Pada Pekerja Yang Terpapar Debu Pada Perusahaan Konstruksi Di Surabaya', The Indonesian Journal of Occupational Safety and Health, 4(1), p. $1 . \quad$ doi: 10.20473/ijosh.v4i1.2015.1-10.

Yustianingrum, L. N. and Adriani, M. (2017) 'Perbedaan Status Gizi dan Penyakit Infeksi pada Anak Baduta yang Diberi ASI Eksklusif dan Non
ASI Eksklusif The Differences of Nutritional Status and Infection Disease in Exclusive Breastfeed and Non Exclusive Breastfeed Toddlers', Amerta Nutrition, 1(4), pp. 415-423. doi: 10.20473/amnt.v1.i4.2017.415423.

Zahra and Assetya, O. (2017) 'Kondisi Lingkungan Rumah Dan Kejadian ISPA Pada Balita Di Indonesia', Jurnal Ekologi Kesehatan, 16(3), pp. 121-129. doi: 10.22435/jek.v16i3.6945.121-129. 